\title{
Length-Weight Relationship and Condition Factor of Auchenoglanis occidentalis (VALENCIENNES, 1775) from Lake Akata, Benue State, Nigeria.
}

\author{
Ikongbeh, O.A. ${ }^{1}$, Ogbe, F.G. ${ }^{\star}$ and Solomon, S.G. ${ }^{1}$ \\ ${ }^{1}$ Dept. of Fisheries \& Aquaculture, University of Agriculture, P.M.B. 2373 Makurdi, Nigeria \\ Dept. of Biological Sciences, Kogi State University, P.M.B. 1008, Anyigba, Kogi State, Nigeria
}

\begin{abstract}
A. occidentalis are economically important, highly valued and threatened freshwater fish species. To contribute to their ecological knowledge the Length-Weight Relationship and changes in the condition factor of A. occidentalis were analyzed from samples collected between May 2008-April 2009, in Lake Akata. A total of 770 fish specimens used for the study were obtained from fishermen operating on Lake Akata. These fishermen use various fishing gears including hand nets, cast nets and gill nets of various standard mesh sizes (20.2, 25.4, and 30.5mm).The aim was to supply basic information on the form of growth of the population of $A$. occidentalis, as well as to assess changes in the fish condition. The Length-weight relationship of fish was estimated from the equation: $W=a \cdot L^{b}$ which was transformed to base 10 logarithm, and condition factor, $(k)$ was determined using the equation: $K=100 . \mathrm{W} / \mathrm{L}^{3}$ The mean weight and standard lengths of A. occidentalis, were $284.6(\mathrm{~g}) \pm 6.9$ and $25.34(\mathrm{~cm}) \pm 0.36$. The growth pattern of both male and femaleA. occidentalisin Lake Akata exhibited negative allometric growth pattern. The Length-Weight relationship equation for male and female of A. occidentalis was described by the equation: were LogW= - 1.1115 +2.4729 Logl and LogW= $1.1725+2.5029$ Logl, respectively. The combined length weight relationship for both sexes was LogW = $1.5644+2.8152 \mathrm{Log}$ L. Fish species in the lake were generally in good condition. The mean condition factor for the combined sexes was $1.53 \pm 0.02$, but individually, male A. occidentaliswere in better condition $(1.53 \pm 0.03)$ compared to the females $(1.52 \pm 0.03)$. There were no significant differences between the monthly condition factors of males and females of A. occidentalis ( $p>0.05$ ). The wet season condition factor of A. occidentalis was higher than dry season values; The seasonal condition factor for A. occidentalis showed that there was no significant differences in the condition factor between dry and wet seasons ( $p>0.05)$. Lake Akata is a good environment for growth, reproduction and survival of the fish species.
\end{abstract}

Keyword:Growth pattern, seasonal condition, A. occidentalis, Lake Akata.

Submitted Date 12 Nov 2012

Accepted Date: 17 Nov 2013

\section{Introduction}

The Claroteidae are a family of catfish found in Africa, which A. occidentalisis a prominent member[1]. Family Claroteidae was carved out of the traditional Bagridae to reflect a monophylectic group of African catfishes [2]. This group was also often formerly placed in Bagridae,[1]. Catfish are heavily exploited and widely cultivated. They are the fourth most widely cultivated freshwater fish after Carp, Salmon and Tilapia [3]. There are about 13 genera and 86 known species of Claroteids in two subfamilies. The sub families are Claroteinae and Auchenoglanidinae. The subfamily Auchenoglanidinae is sometimes classified as a separate family Auchenoglanidinae. Distribution of Claroteidae includes the Nile River basin and most of west and central Africa south to the tropic of Capricorn, including the East African lakes. The most commonly known species are the (Giraffe catfish) A. occidentalis, (African big eye catfish) C. longipinnus,Leptoglanis, and Parauchenoglanis. A. occidentalis are of ecological and economical important in Akata Lake. A. occidentalis are found in Africa in the Nile, Lake Chad, West Africa, Congo-lualaba River system, East African lakes, Omo River and Giuba River.

A. occidentalis inhabit lakes and large rivers, they occur in shallow water with muddy bottom [4]. A. occidentalisare fairly common in October to December especially in swamps and rivers [1]. Although a sizeable amount of literature exists on their biology, especially their length-weight relationships and condition factor.

The length-weight relationship is very important for proper exploitation and management of the population of fish species [5].They are also useful for assessing the relative well being of the fish population.

Length-weight relationships allow fisheries scientists to convert growth in- length equations to growthin-weight in stock assessment models [6];[7], estimate biomass from length frequency distributions [8];[9], 
compare life history and morphological aspects of populations inhabiting different regions [7] and calculate fish condition [8]. The length-weight relationships of some fishes in Nigerian waters have been studied: Researchers such as[10] studied the length-weight relationships of five fish species (C.gariepinus, I. africana, C. nigrodigitatus, C. walkerand E. fimbriata) in Epe Lagoon, Lagos, Nigeria while [11] studied the length-weight relationships of 35 fish species from Badagry creek, Lagos, Nigeria, [12]studied the lengthweight relationships of $H$. forskalli and $A$. nurse in Lower River Benue,[13,14] studied the length-weight relationships of $C$. nigrodigitatus and $B$. docmac, from Lake Akata, Benue State, Nigeria. Other researchers such as [15],[16],[17], and [18], have studied the length-length and length-weight relationships of various fish species from different waters.

Condition factor is an index of the degree of fatness or well being of a species [19]. The study of condition factor is important to understand the life cycle of fish species and contribute to an adequate management of the species and to the maintenance of the ecosystem equilibrium [20]. Condition index may be used to determine the reproductive time of fish species without sacrificing the organisms, and this could be a valuable tool to develop monitoring programmes for the species fisheries and culture programs [21]. Condition factors of different tropical fish species based on size, sex, maturity stages as well as seasons have been investigated and reported [22] reported $M$. cephalus in Bonny estuary, [23] reported C. chana in fresh water swamps of Niger Delta and, [24] reported A. occidentalis from the Lower Benue River, [25] reported $M$. electricus from the Lower Benue River,[26] reported ten fish species from the lowerNun River, [27] reported $C$. laticeps from the fresh water reaches of the lower Nun river and [13,14] also reported C. nigrodigitatus, and $B$. docmac from Lake Akata, Benue State, Nigeria.

The biology of fish species of Lake Akata, have been poorly investigated. There is no published account on the biology of fish species of Lake Akata. It is therefore necessary to carry out a comprehensive study on the biology of fishes of this very important recreational lake aimed at good management. The aim of the present study provides information on the length-weight relationship and condition factor of $A$. occidentalis in Lake Akata.

\subsection{Study area}

\section{Materials and methods}

The study area, Lake Akata is an ox-bow lake of the River Katsina-Ala and lies between longitude $9^{\circ} 16^{\prime}$ and $9^{\circ} 17^{\prime}$ East and latitude $7^{\circ} 11^{\prime}$ and $7^{\circ} 13^{\prime}$ North (Fig. 1). The host town, Katsina-Ala is a riverside resort with a unique feature and the scenic beauty of savannah landscape, supplemented by the famous River Katsinaala with extensive fadama flood plain covered by numerous lakes scattered over the flood plain one of such lake is the Lake Agbo [28]

\subsection{Sample Collection}

A total of 770 individuals of $A$. occidentalis were randomly sampled monthly for one year and usually in the mornings between 7.00am - 9.00am and in the evenings between 4:30pm - 6:30pm. The period of the study was from May, 2008 to April, 2009.The fish specimens used for the study were obtained from fishermen operating on Lake Akata. These fishermen use various fishing gears including hand nets, cast nets and gill nets of various standard mesh sizes $(20.2,25.4$, and $30.5 \mathrm{~mm})$. 


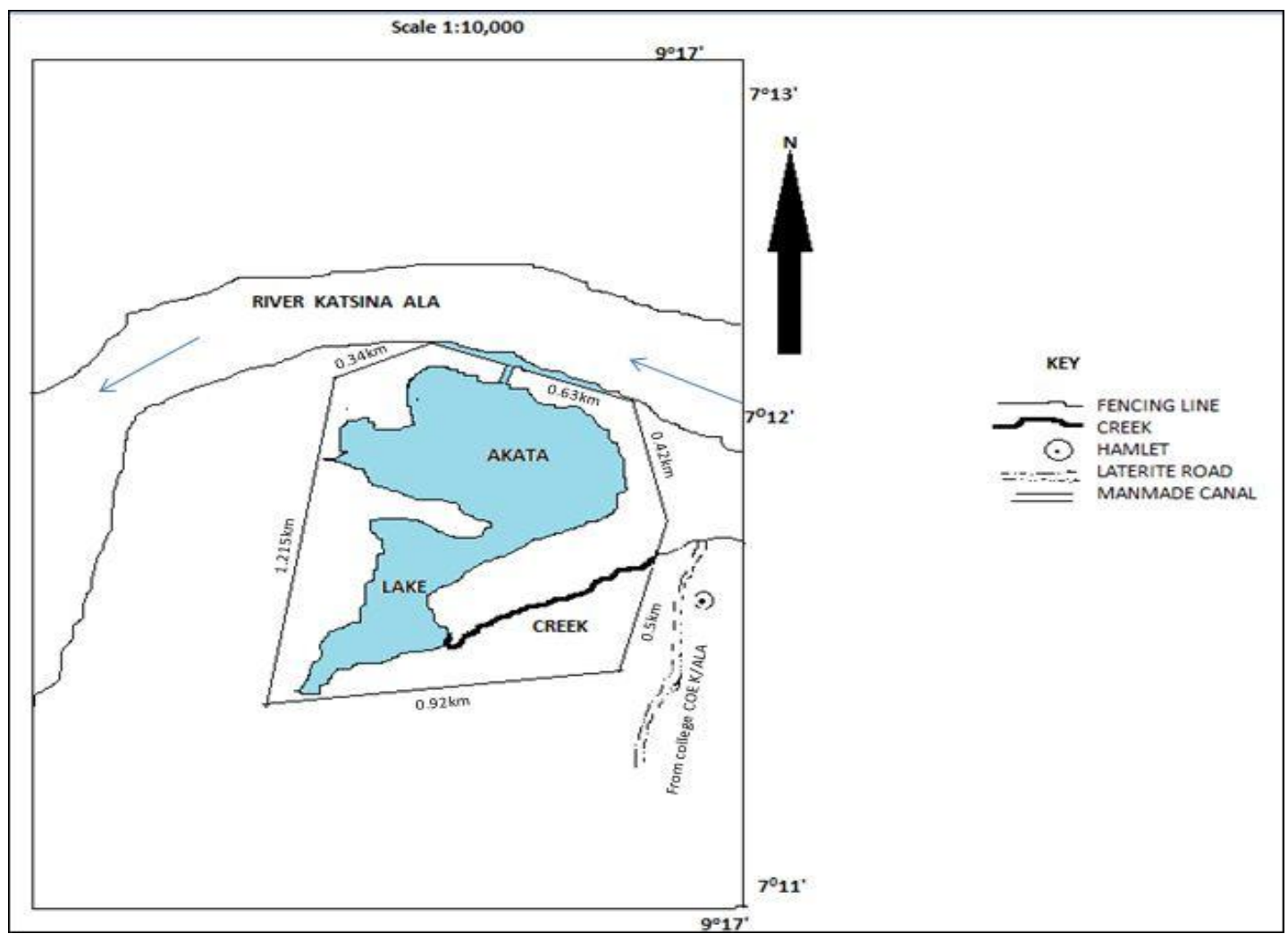

Figure 1: Map of Lake Akata

Source: Ministry of Agriculture and Natural Resources, Makurdi, Benue State. landing sites.

Canoes were used as fishing craft. Length and weight measurements were taken directly from the The total and standard lengths were measured with a meter rule on measuring board according to [29]. The sex of each fish sample was determined by visual observation using genital evidence.

Length-weight relationship of fish was estimated from the equation: $W=a \cdot L^{b}$ [30].The relationship was transformed into a linear form using the logarithm equation: $\log W=a+b \log L$. Where, $\mathrm{W}=$ weight of fish $(\mathrm{g}), \mathrm{L}=$ standard length of fish $(\mathrm{cm}), \mathrm{a}=$ regression constant and $\mathrm{b}=$ the allometric coefficient.

For males and females and both combined sexes by least square regression method.

The condition factor, (k) was determined using the equation: $K=100 . \mathrm{W} / \mathrm{L}^{3}$ after [31]. Where, $\mathrm{K}=$ the condition factor, $\mathrm{W}=$ Weight of fish in $(\mathrm{g})$ and $\mathrm{L}=$ Standard Length of fish $(\mathrm{cm})$.

According to [32], fish in good condition will have high $\mathrm{K}$-value greater than 3, than those in poor condition.

\subsection{Length-Weight Relationship}

\section{Results}

The Log-Log graphs showing the regression analysis of males, females, and combined sexes were (Fig. $2,3$ and 4$)$ respectively.

The "a" value for male and female A. occidentalis was -1.1115 and -1.1725 respectively, while the combined value for both sexes was -1.2112 . All the three exponents of ("b") obtained for males, females and both sexes combined were less than 3 ; this means the growth pattern was allometric. The exponent ("b") values for male and female of the species were 2.4729 and 2.5029 respectively. Both males and females exhibited negative allometric growth pattern.

The Length-Weight relationship equation for male and female $A$. occidentalis is expressed by the regression equation: $\log W=-1.1115+2.4729 \operatorname{Logl}\left(\mathrm{r}^{2}=0.9348\right)$ and $\log \mathrm{W}=-1.1725+2.5029 \operatorname{Logl}\left(\mathrm{r}^{2}=\right.$ $0.9368)$, respectively. The combined length weight relationship for both sexes is expressed by the regression equation: $\log \mathrm{W}=-1.2112+2.5377 \operatorname{Logl}\left(\mathrm{r}^{2}=0.9406\right)$. There was a higher correlation coefficient value in the length-weight for both sexes of $A$. occidentalis. The correlation coefficients were all positive and highly significant. The females weighed more than the males. 


\subsection{Condition Factor}

The mean condition factor $(\mathrm{k})$ of $A$. occidentalis is presented in Table 1 . The mean condition factor was $1.53 \pm 0.02$ for $A$. occidentalis (combined Sexes). The results indicated that there were no significant differences between the condition factors of male and female of $A$. occidentalis $(\mathrm{p}>0.05)$. The seasonal variation in mean monthly condition factor $(\mathrm{k})$ of A. occidentalis males and females in dry season was 1.58 in March, while in the wet season males was 1.69 in August, and females was 1.72 in October. Maximum k-values were observed in August, while the minimum k-values were observed in April in the males. The highest k-value in the females was recorded in October whereas the least was recorded in August (Fig. 5). The condition factor for $A$. occidentalis in dry season $(1.52 \pm 0.02)$ was significantly lower than that $(1.53 \pm 0.03)$ in wet season $(\mathrm{p}>0.05)$ (Table 2).

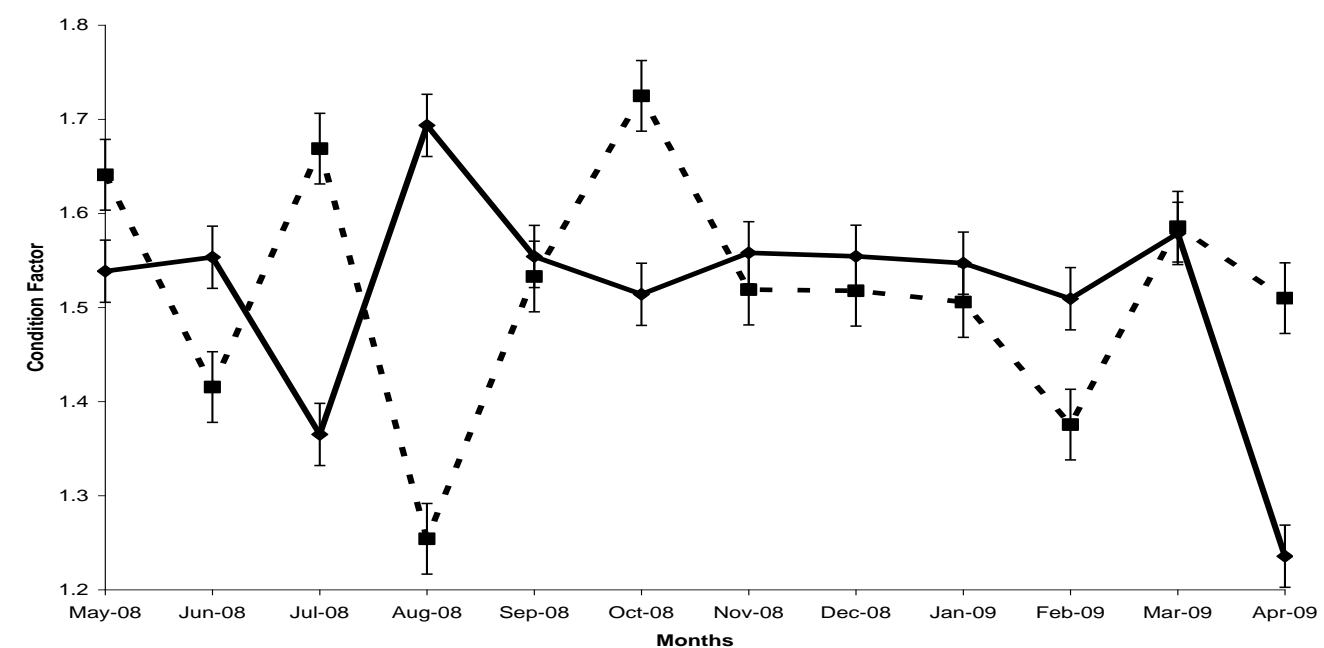

Figure 5: Monthly Variation in Condition Factor of Auchenoglanis occidentalis from Lake Akata in Katsina-Ala.

\section{Discussion}

The growth exponent ' $b$ ' value for the combined sexes reported in this study is similar to that reported for $P$. pardalis in Malaysia peninsula (2.53) by [33]. However, the combined ' $b$ ' value for both sexes as reported by the authors (2.53) is comparable with (2.53) reported in the present study. The difference can be attributed to contrast in weather conditions between Nigeria and Malaysia. The correlation coefficient was all positive and highly significant for A. occidentalis in Lake Akata which indicates that the length increases with increase in weight of the fish. This is in agreement with previous studies on different fish species from various water bodies [34]; [35]. However, [36] reported allometric growth pattern for A. occidentalis in River Rima, North-western Nigeria and the ' $b$ ' value is consistent with the ' $b$ ' values reported for A. occidentalis in this study.[14]reported allometric growth pattern for B. docmac, from Lake Akata, Benue State, Nigeria. Isometric growth pattern was also reported for $C$. auratus [37] and for $C$. nigrodigitatus [10];[38].

It was observed in the present study, that mean condition factor for A. occidentalis were greater than "1" which indicates that fish species are doing well in the Lake, meaning that increase in length brought about the proportional increase in weight. [39] Who reported good condition in about 10 species of fishes from River Rima.

The condition factor of $A$. occidentalis in this study is favourably comparable with condition factors of different tropical fish species investigated and reported by [40]. The condition factors of male and female sexes of A. occidentalis ( $\mathrm{K}=1.53$, and 1.52 respectively) in Lake Akata is lower than values (2.26 and 2.27 respectively) reported for $A$. occidentalis in River Rima, North western Nigeria by [36]. There were no significant differences between the condition factors of male and female of A. occidentalis $(\mathrm{p}>0.05)$. [41] reported that the males of $C$. nigrodigitatus in Aiba reservoir in Iwo, Osun state beig in a better condition than the females. The condition factor for the combined sexes of A. occidentalis in dry season (1.52 \pm 0.02$)$ was significantly lower than that $(1.53 \pm 0.03)$ in wet season $(\mathrm{p}>0.05)$. Seasonal variation in the condition factor of fish has been reported for L. lepidus and B. nurse by [42], P. barbarous in Imo River [43], [13, 14] also reported $C$. nigrodigitatus, and $B$. docmac from Lake Akata, Benue State, Nigeria. Condition factor is not constant for a species or population over a time interval and might be influenced by both biotic and abiotic factors such as feeding regime and state of gonadal development [44]. The higher ' $\mathrm{k}$ ' recorded during the rains may be due to 
more food availability, favourable environmental condition and gonadal development. Similar findings were reported for $\mathrm{H}$. longifilis from Idodo River [45]. [46]Reported that the low condition factors observed during the dry season may be attributed to physiological stress due to changes in physical and chemical conditions of the habitat. There are also suggestions that fish condition can be influenced by certain extrinsic factors such as changes in temperature and photoperiod [47]. For the P.pardalisin Langat River, the temperature and photoperiod elements might not be significant factors because Malaysia in general experiences no great difference on those parameters throughout the year compared with the temperate countries. Factors known to influence a prevailing condition factor include conditions of food, modifications in food resources, increase or decrease in feeding activity, density or population changes, or climate, the period and duration of gonadal maturation among others [48].

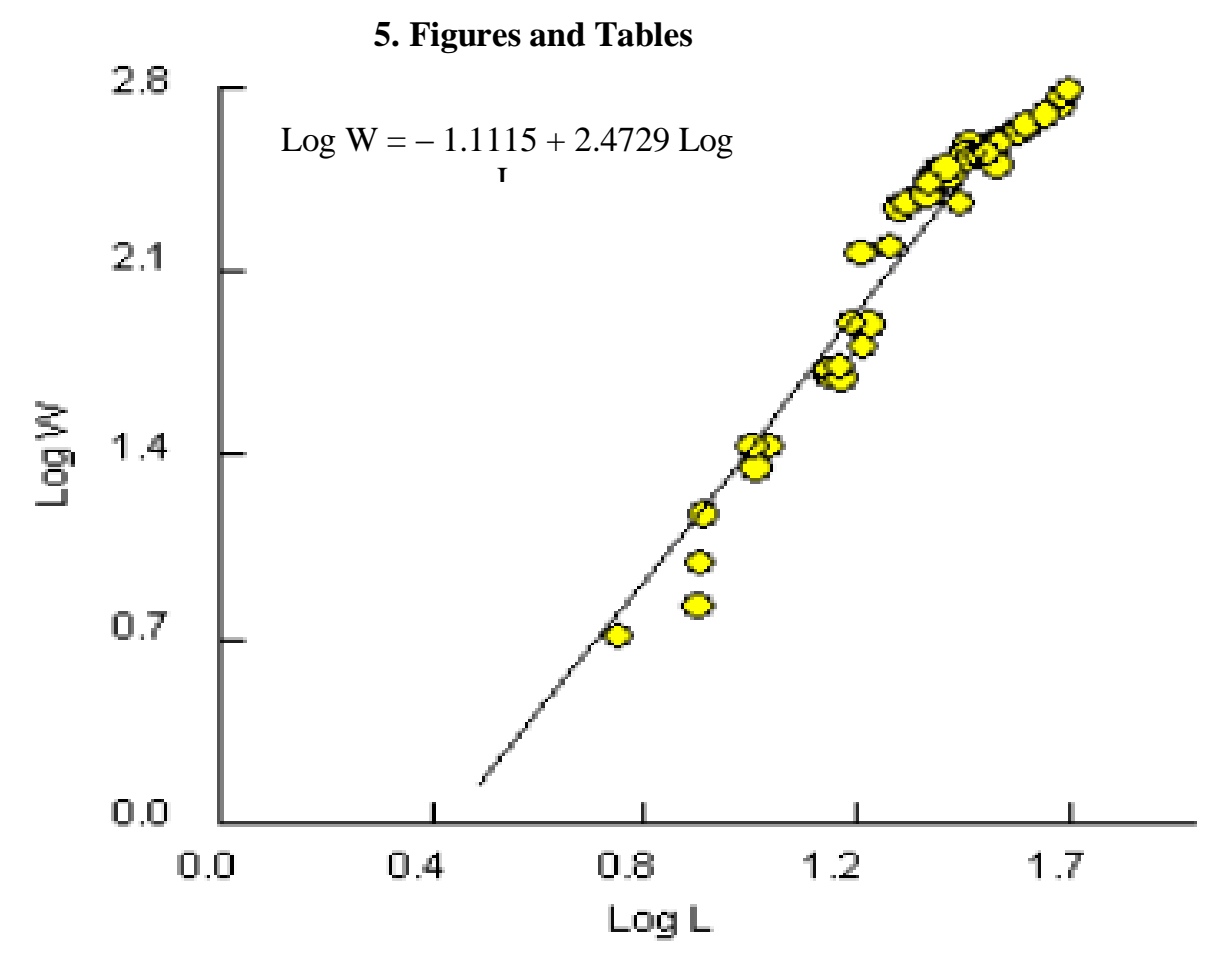

Figure 2: Length-Weight Relationship of Auchenoglanis occidentalis Males from Lake Akata, KatsinaAla.

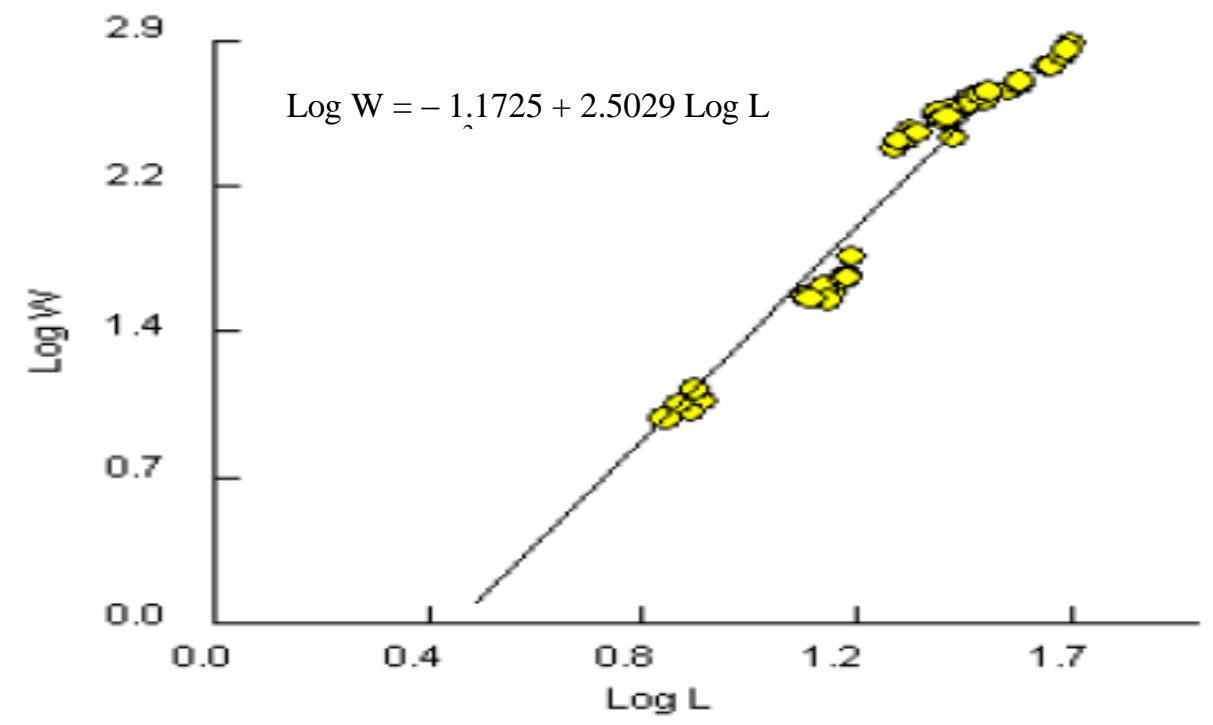

Figure 3: Length-Weight Relationship of Auchenoglanis occidentalisFemales from Lake Akata, KatsinaAla. 


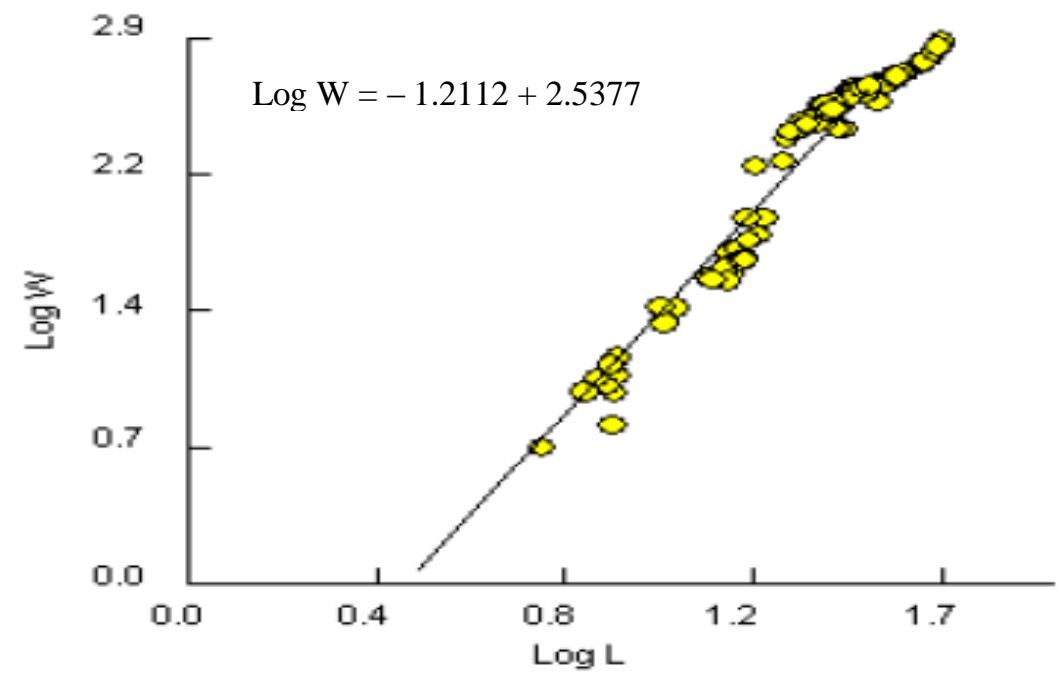

Figure 4: Length-Weight Relationship of Auchenoglanis occidentalis (Combined Sexes) from Lake Akata, Katsina-Ala.

Table 1: Mean Condition Factor of A. occidentalis in Lake Akata, Katsina-Ala.

\begin{tabular}{lllll}
\hline Sex & $\mathbf{N}$ & Condition Factor $(\mathbf{K})$ & T-test & P value \\
\hline Male & 391 & $1.53 \pm 0.03$ & -0.51 & 0.61 \\
Female & 379 & $1.52 \pm 0.03$ & & \\
\hline Combined & 770 & $1.53 \pm 0.02$ & & \\
\hline
\end{tabular}

Table 2: Seasonal Variation in Condition Factors of A. occidentalisin Lake Akata, Katsina-Ala.

\begin{tabular}{lllll}
\hline Season & N & Condition Factor $(\mathbf{K})$ & T-test & P value \\
\hline Wet & 319 & $1.53 \pm 0.03$ & -0.16 & 0.869 \\
Dry & 451 & $1.52 \pm 0.02$ & & \\
\hline
\end{tabular}

\section{Conclusion}

In conclusion, both sexes of $A$. occidentalis exhibited negative allometric growth pattern. There was a higher correlation coefficient value in the length-weight for both sexes of A. occidentalis. The correlation coefficients were all positive and highly significant. The condition factor of $A$. occidentalis in dry season $(1.52 \pm 0.02)$ was significantly lower than that $(1.53 \pm 0.03)$ in wet season $(\mathrm{p}>0.05)$.

\section{Acknowledgements}

The authors appreciate the Department of Fisheries and Aquaculture, University of Agriculture, Makurdi, for approving the use of the laboratory and providing necessary facilities for this study.

\section{References}

[1]. J. S.Nelson, Fishes of the World(John Wiley and Sons, Inc., 2006).

[2]. T.Berra, Freshwater fish distribution (Academic Press, San Diego, California, USA, 2001) 604p.

[3]. L. Etim, P.E. Lebo, and R.P. King, The dynamics of an exploited population of siluriod catfish (Schilbe intermidius Rueppel, 1832). In the Cross River, Nigeria,Fisheries Research, 40, 1999, 295-307.

[4]. D.H. Eccles, FAO species identification sheet for fishery purposes, Field guide to the freshwater fishes of Tanzania. Prepared and published with the support of the United Nations Development programme (Project URT/87/016).FAO, Rome, 1992, $145 \mathrm{P} / 56$.

[5]. A. Anene, Condition factors of four cichlid species of a man-made lake in Imo State, Southeastern, Nigeria,Turkish journal of fisheries and aquatic sciences, 5, 2005, 43-47.

[6]. T.P. Morato, P. Afonso, P. Lourinho, J.P. Barreiros, R.S. Santos and R.D.M. Nash, Length-weight relationships for 21 coastal fish species of the Azores, North-Eastern Atlantic,Fisheries Research,50, 2001, 297-302.

[7]. D. K. Moutopoulos, and K. I. Stergiou, Length-weight and length-length relationships of fish species from Aegean Sea (Greece),Journal of Applied Ichthyology, 18 (3), 2000, 200-203.

[8]. G. Petrakis, and K.I. Stergiou, Weight-Length relationships for 33 fish species in Greek waters,Fisheries Research,21, 1995, 465469.

[9]. J. Dulčić, and M. Kraljević, Weight -length relationships for fish species in the eastern Adriatic (Crotian waters),Fisheries Research, 28, 1996, 243-251.

[10]. O.O. Fafioye, and O.A. Oluajo, Length-weight relationships of five fish species in Epe Lagoon, Nigeria,African journal of Biotechnology, 4,2005, 749-751.

[11]. J.I. Agboola, and M.A. Anetekhai, Length-weight relationships of some fresh and brakish water fishes in Badagry Creek, Nigeria, Journal of Applied Ichthyology,24, 2008, 623-625.Doi: 10.1111/j. 1439-0426.2008.01079.x. 
[12]. F.G. Ogbe, G. A. Ataguba, and E. H. Okosuwe, Feeding habits and growth parameters of Hydrocynus forskalii and Alestes nurse in River Benue, Nigeria,Journal of Applied Biosciences, 11, 2008, 576-583.

[13]. O.A, Ikongbeh, F.G. Ogbe, and S.G. Solomon, Length-weight relationship and condition factor of Chrysichthyes nigrodigitatus from Lake Akata, Benue State, Nigeria,Nigerian journal of fisheries, 9(1), 2012a.

[14]. O.A, Ikongbeh, F.G. Ogbe, and S.G. Solomon, Length-weight relationship and condition factor of Bagrus docmac from Lake Akata, Benue State, Nigeria,Journal of Animal and Plant Science, 15 (3), 2012b, 2267-2274.

[15]. K.D. Simon, and A.G. Mazlan, Length-weight and length-length relationships of Archer and Puffer fish species, Open fish Science Journal, 1, 2008, 19-22.

[16]. B. Zorica, and G. Sinuvcic, Biometry, Length-length and length-weight relationships of juveniles and adults of Atlantic bonito, Sarda sarda, in the eastern Middle Adriatic Sea,Acta Adriat, 49, 2008, 65-72.

[17]. B.R. Subba, R.K. Bhagat, and S. Adhikaree, Studies on length-weight and length-length relationship of a freshwater fish Gudusia godanahiae from Biratnagar, Nepal,Nature, 7, 2009, 218-221.

[18]. G.A. Hajjej, Hattour, A. Hajjej, H. Allaya, O. Jarboui and A. Bouain, Biometry, Length-length and length-weight relationships of little tuna Euthynnus alletteratus in the Tunisian waters,Journal of fisheries Aquatic Science, 6, 2011, 256-263.

[19]. T.B.Bagenal, and F.W. Tesch, Age and Growth. In: Bagenal, T. (Ed.), Methods of Assessment of fish production in fresh waters,(Oxford Blackwell Scientific Publication, 1978) 101-136.

[20]. M. Haruna, and A.H. Bichi, Studies on the length-weight relationship and condition factor of the cichlids of Tomas Lake, Kano, Nigeria,Biological Environmental Science Journal for the Tropics. 2, 2005, 94-100.

[21]. M.Arellano-Martinez, and B.P. Ceballosvazquez, Reproductive activity and condition index of Holocanthus passer (Teleostei: Pomacanthidae) in the Gulf of California, Mexico, Revita Biologia Trop. 49, 2001, 939-943.

[22]. S.A,Hart, The Biology of Mugil cephalus in Bonny River estuary. M.Sc. Thesis University of Port-Harcourt, Nigeria, 1997, 42.

[23]. J.F.Alfred-Ockiya, Length-weight relationship of snake head fish Chana chana from the fresh water swamps of Niger Delta,Journal of Aquatic Sciences, 15, 2000, 12-14.

[24]. F.G. Ogbe, A. Kappo, and J.O. Cheikyula, Age and Growth Studies of Auchenoglanis occidentalis (Valenciennes, 1775) from Lower Benue River using Bhattacharya Method,The Zoologist 2(2), 2003, 36-45.

[25]. F.G.Ogbe, andG.A. Ataguba, Studies on the feeding habits and growth patterns and reproductive biology of Malaptererus electricus, (Gmelin,1789) in Lower Benue River, Nigeria. Biological and Environmental Sciences Journal for the Tropics,5(1), $2008,169-176$.

[26]. A.I.Hart, and J.F.N. Abowei, A study of the length-weight relationship, condition factor and age of ten fish species from the lower Nun River, Niger Delta,African Journal of Applied Zoology and Environmental Biology, 9, 2007, 13-19.

[27]. J.F.N.Abowei, and A.O. Davies, Some population parameters of Clarotes laticeps (Rupell, 1829) from the fresh water reaches of the lower river, Niger Delta, Nigeria,American Journal of Scientific Research, 2, 2009, 15-19.

[28]. (MANR). Ministry of Agriculture and Natural Resources, Makurdi, Benue State. (Unpublished).

[29]. A.A.Olatunde, The distribution, abundance and trends in the establishment of the Family Schilbidae (Osteichthyes: Siluriformes) in lake Kainji, Nigeria, Hydrobiologia,56, 1977, $69-80$.

[30]. D.Pauly, Fish population dynamics in tropical waters: a manual for use with programmable calculators,ICLARM Studies and Reviews8, 1984, 325.

[31]. W.E.Ricker, Computation and interpretation of biological statistics of fish population,Bull Fish Research, Rd can 191, 1975, 1-382.

[32]. R.J.Wooton, Fish ecology,(Blackie and son limited chapman and Hall, New York, 1992) 200pp

[33]. A. Samat, M. N. Shukor, A.G. Mazlan, A.Arshad, and M.Y.Fatimah, Length-weight Relationship and Condition Factor of Pterygoplichthys pardalis(Pisces: Loricariidae) in Malaysia Peninsula, Research Journal of Fisheries and Hydrobiology, 3(2), 2008, 48-53.

[34]. P. A.Layèyè,Length-weight and length-length relationships of fishes from the Ouèmè River in Benin (West Africa), Journal of Applied Ichthyology,22, 2006, 330-333.

[35]. A.A.Ayoade, and A.O.O. Ikulala, Length-weight relationship, condition factor and stomach contents of Hemichromis bimaculatus, Sarotherodon melanotheron and Chromidotilapia guenteri (Perciformes: Cichlidae) in Eleiyele Lake, Southwestern Nigeria,Revita Biologia Trop., 55(3-4), 2007,969-977.

[36]. B.A.Shinkafi, and J.K. Ipinjolu, Morphometric relationships and relative condition factor of Auchenoglanis occidentalis (Cuvier and Valenciennes) from River Rima, North-western Nigeria,Journal of fisheries international,5(4), 2010, 61-66.

[37]. R.B.Ikomi, and O. Odum, Studies on the aspects of the ecology of the catfish Chrysichthyes auratus Geoffrey st. Hilaire (Osteichthyes; Bagridae) in the River Benin (Niger Delta, Nigeria), Fisheries Research, 35, 1998, 209-218.

[38]. B.O. Offem, Y. Akegbejo-Samsons, and I.T. Omoniyi, Diet, size and reproductive biology of the silver catfish, Chrysichthyes nigrodigitatus (Suliformes Bagridae) in the Cross River, Nigeria, Revita Biologia Trop., 56, 2008, 1785-1799.

[39]. I.Magawata, Growth dimensions and body yield of some fish species in River Rima and Goronyo Dam in North western Nigeria.Ph.D. Thesis, Department of forestry and fisheries, Usman Danfodiyo University, Sokoto, Nigeria, 2008.

[40]. M.Lizama, A.P.De Los, and A.M.Ambroso, Condition factor in nine species of fish of the Characidae family in the upper Parana River floodplain, Brazil,BrazilianJournal of Biology, 62(1), 2002, 113-124.

[41]. O.E.Atobatele, andA.O. Ugwumba, Condition factor and diet of Chrysichthys nigrodigitatusandChrysichthys auratus (Siluriformes: Bagridae) from Aiba Reservoir, Iwo, Nigeria,Revita Biologia Trop., (International Journal for Tropical Biology),59(3), 2011, 1233 -1244 .

[42]. M.Karabatak, The time of spawning and seasonal variations in length-weight relationship and condition of chub, Leuciscus lepidus (Heckel,1834) in Lake Beysehir (Turkey), Acta Hydrobiol., 39, 1997, 39-46.

[43]. R.P. King, and M.T. Udo,periophthalmus barbarusLength -weight relationship of the mudskipper in Imo River estuary, Nigeria,NAGA ICLARMQUARTERLY, 19(2), 1996, 27.

[44]. J.K.Saliu, Observation on the condition factor of Brycinus nurse (Pisces: Cypriniformes, Characidae) from Asa Reservior, Ilorin, Nigeria,Tropical Freshwater Biology, 10, 2001, 9-17.

[45]. C.I.P. Anibeze, Length-weight relationship and relative condition factor of Heterobrachus longifilis (Valenciennes) from Idodo River, Nigeria, NAGA ICLARMS QUARTELY, 23, 2000, 34-35.

[46]. S.B.Ekanem, Some reproductive aspects of Chrysichyes nigrodigitatus (Lacepede) from Cross Iver, Nigeria, NAGA ICLARMS QUARTELY,23, 2000, 24-28.

[47]. J.H.,Youson, J.A. Holmes, J.A. Guchardi, J.G. Seelye, R.E. Beaver, J.E. Gersmehl, S.A. Sower, and F.W.H. Beamish, Importance of condition factor and the influence of water temperature and photoperiod on metamorphosis of sea lamprey, Petromyzon marinus,Canadian Journal of Fish and Aquatic Science, 50, 1993, 2448-2456.

[48]. A.H.Weatherly, and H.S. Gill, The biology of fish growth,(London Academic press, 1987) pp: 43. 